\title{
Sodium Bearing Waste Processing Alternatives Analysis
}

J. Murphy

B. Palmer

K. Perry

December 2000

Idaho National Engineering and Environmental Laboratory Bechtel BWXT Idaho, LLC 


\title{
Sodium Bearing Waste Processing Alternatives Analysis
}

\author{
James Murphy \\ Brent Palmer \\ Keith Perry
}

December 2000

\section{Idaho National Engineering and Environmental Laboratory Idaho Falls, Idaho 83415}

\author{
Prepared for the \\ U.S. Department of Energy \\ High Level Waste Program Director \\ Under DOE Idaho Operations Office \\ Contract DE-AC07-99ID13727
}




\section{ABSTRACT}

A multidisciplinary team gathered to develop a BBWI recommendation to DOE-ID on the processing alternatives for the sodium bearing waste in the INTEC Tank Farm. Numerous alternatives were analyzed using a rigorous, systematic approach. The data gathered were evaluated through internal and external peer reviews for consistency and validity. Three alternatives were identified to be top performers: Risk-based Calcination, MACT to WIPP Calcination and Cesium Ion Exchange. A dual-path through early Conceptual design is recommended for MACT to WIPP Calcination and Cesium Ion Exchange since Risk-based Calcination does not require design. If calcination alternatives are not considered based on giving Type of Processing criteria significantly greater weight, the CsIX/TRUEX alternative follows CsIX in ranking. However, since CsIX/TRUEX shares common uncertainties with CsIX, reasonable backups, which follow in ranking, are the TRUEX and UNEX alternatives. Key uncertainties must be evaluated by the decision-makers to choose one final alternative. Those key uncertainties and a path forward for the technology roadmapping of these alternatives is provided. 


\section{SUMMARY}

In December 1999, the Department of Energy Idaho Operations Office (DOE-ID) assigned Bechtel BWXT Idaho LLC (BBWI) to examine the waste processing options in the Idaho High-Level Waste and Facilities Disposition (HLW\&FD) Environmental Impact Statement (EIS) and recommend a process for treating the sodium bearing waste, which is bounded by the EIS options, by May 1, 2000. A broad-based BBWI Core Team was assembled with expertise that could take advantage of work performed over the past 5-7 years. This report comprises the results of over 4000 man-hours of data collection and analysis by the Core Team and other supporting personnel.

The BBWI Core Team utilized a five step systematic process. These five steps were: (1) identify alternatives, (2) identify analysis requirements, (3) collect and make data consistent among alternatives, (4) analyze results, and (5) document and communicate results. Facilitated meetings were held to identify alternatives for consideration in this analysis and the Core Team added hybrid alternatives during the course of the analysis. Nine alternatives were fully evaluated and are graphically described in Figures A and B. A creditable systematic analysis requires consistent requirements, rules for analysis, and goals. These parameters were set early in the activity and reviewed with HLW Program management in BBWI and DOE-ID. As the goals defined the desirable qualities of the alternatives, the criteria and defined measures of effectiveness (MOEs) were used to describe the relative performance between the alternatives. Having developed the potential discriminating criteria for the process, it was then necessary to identify what information was known and not known for a given alternative. Although data were available for collection and assimilation, generation of additional information was necessary to fill gaps in the existing data. Iteration became an important factor among team members to ensure the data generated for comparison had an equivalent basis. Many criteria were evaluated for potential discrimination among the alternatives. The criteria and associated data that did not provide discrimination were set aside. The quantified data for each discriminator were placed into three qualitative performance levels; high, moderate, and low for comparison purposes and to eliminate comparisons of insignificant differences. DOE-ID and the Idaho National Engineering and Environmental Laboratory (INEEL) HLW Program management established the need for an external peer review to validate the effort invested and data collected by the Core Team. The review team was chartered to validate both the recommendation process that the Core Team used and the data gathered to support the recommendation. The review validated the methodology and data used by the Core Team in these alternatives comparisons. Summary analysis results are provided in Table A. A Monte Carlo sensitivity analysis was used to measure the effect of changing weighting factors across a broad range. The analysis revealed that in $99.6 \%$ of the cases, the same three alternatives, Risk-Based, CsIX, and MACT to WIPP, were the top performers. If calcination alternatives are not considered based on giving Type of Processing criteria significantly greater weight, the CsIX/TRUEX alternative follows CsIX in ranking. However, since CsIX/TRUEX shares common uncertainties with CsIX, reasonable backups, which follow in ranking, are the TRUEX and UNEX alternatives.

The evaluation results demonstrate that the weighting factor analysis was useful in obtaining the top performers; however, the weighting analysis did not provide enough discrimination to support a final selection from among the top three alternatives. To select the best alternative among the finalists, the Core Team identified the key uncertainties that, if additional information were available, could provide the basis for a single, final selection. For example, the Risk-Based alternative has the high risk uncertainty of obtaining a permit to operate without upgrading the NWCF, which could lead this alternative to a go/no-go determination.

Based on the report analyses and the resulting conclusions, the following BBWI recommendations are made to DOE-ID: 
1. Decide whether to pursue the Risk-Based Calciner Option based on the probability of obtaining a permit.

2. If the Risk-Based Option is not pursued:

$>$ Go down the dual path of MACT-WIPP \& CsIX(or CsIX \&TRUEX if calcination options are not considered further) until key uncertainties are resolved

$>$ Focus technology development immediately on key uncertainties

$>$ Initiate Conceptual Design for selected alternatives as soon as required information is available. Conceptual Design must begin no later than July 2000 for MACT-WIPP and April 2001 for CsIX, if the 2012 deadline for treating the SBW is to be met. Specific schedule information for the other alternatives can be found in Appendix K.

$>$ Initiate acceptance of our material into final disposition locations (WIPP \& Hanford)

$>$ Make final selection when key uncertainties are resolved.

3. Initiate discussions with the State of Idaho regarding Sodium Bearing Waste (SBW) classification and disposition.

4. Increase focus on liquid waste feed characterization (and entrained solids characterization if CsIX is pursued).

Path forward actions are described that will ensure continued progress towards processing the sodium bearing waste and emptying the Tank Farm by the 2012 deadline. 


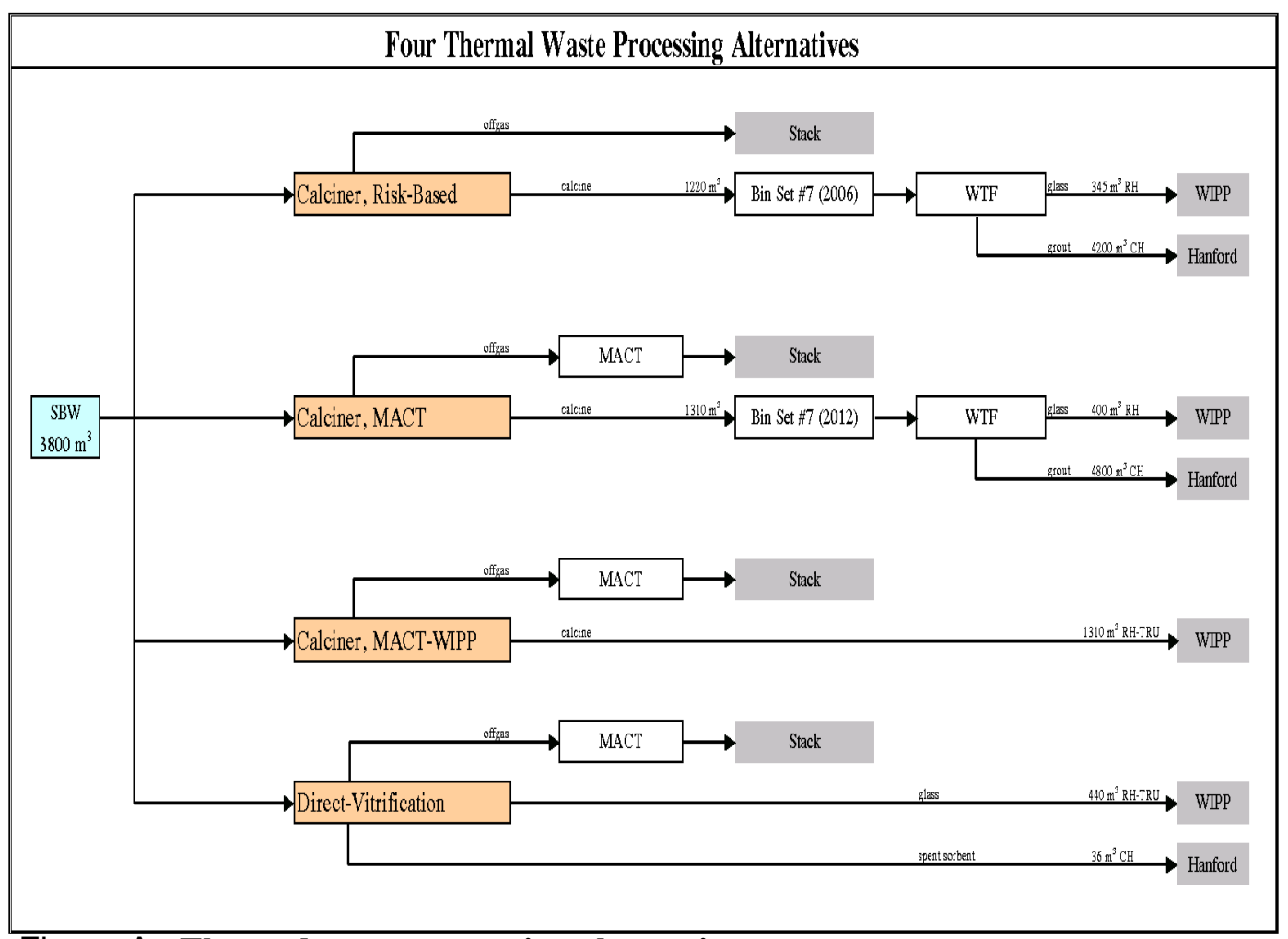

Figure $A$. Thermal waste processing alternatives.

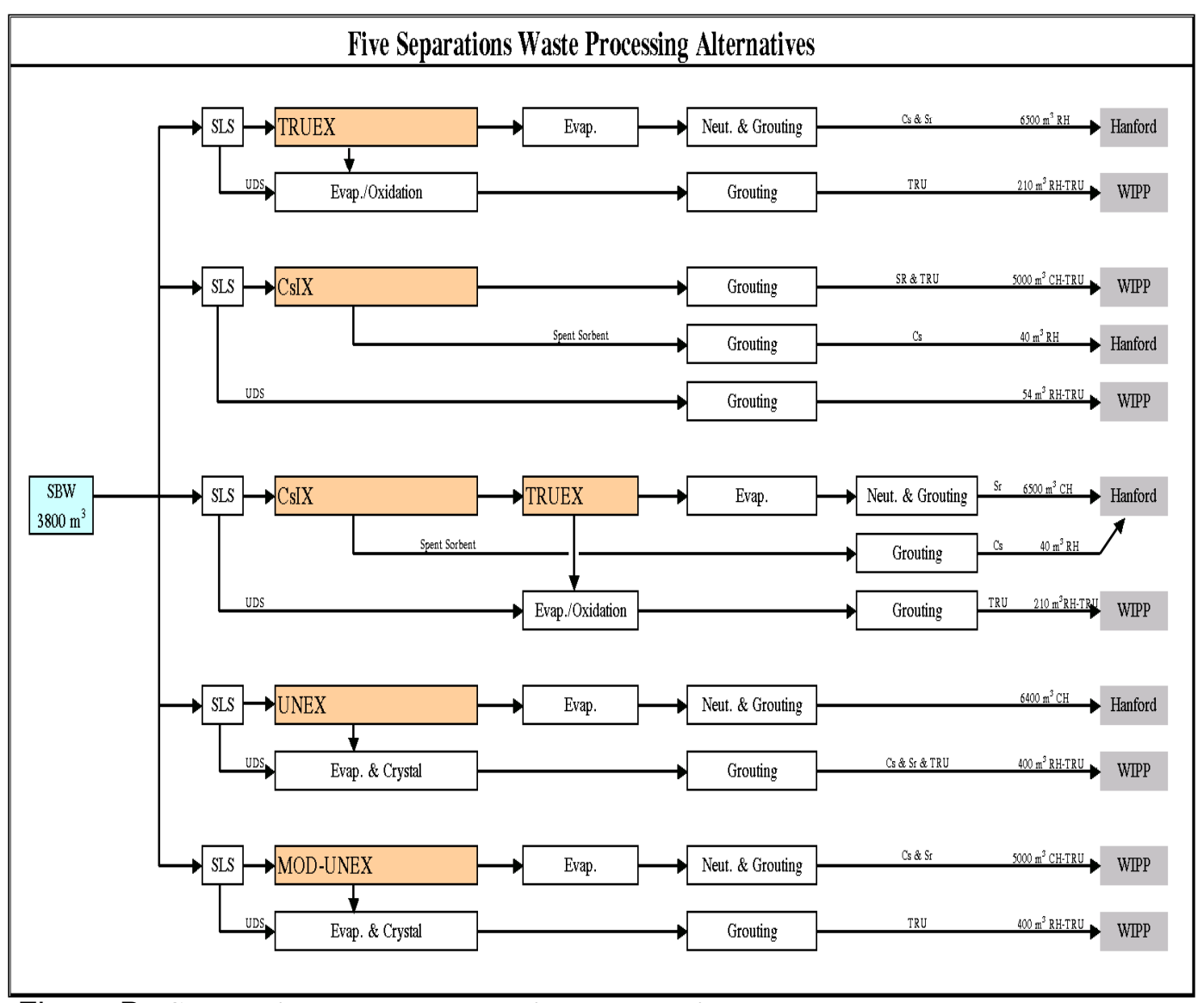

Figure B. Separations waste processing alternatives. 


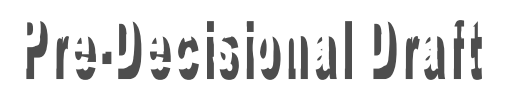

Table A. Summary analysis of the nine alternatives.

\begin{tabular}{|c|c|c|c|c|}
\hline 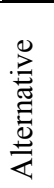 & $\begin{array}{l}\text { Unit Operations/ } \\
\text { Technologies*** }\end{array}$ & Key Benefits & Key Disadvantages & Key Uncertainties \\
\hline 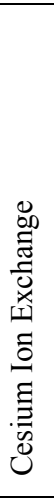 & $\begin{array}{ll}\text { 1. } & \text { Solid/Liquid Separation } \\
\text { 2. } & \text { Ion Exchange } \\
\text { 3. Neutralization \& grouting } \\
\text { 4. } \\
\text { HAW/TRU handling \& } \\
\text { storage } \\
\text { 5. UDS grouting }\end{array}$ & $\begin{array}{ll}\text { - } & \text { Low total cost } \\
\text { - } & \text { Completes processing SBW by } 2012 \text { deadline } \\
\text { - } & \text { Lowest technical risk of new processes (more than } \\
\text { - } & \text { one ion exchange material available) } \\
\text { - } & \text { Sits within anticipated disposal volume availability } \\
\text { - } & \text { Uses non-thermal process } \\
\text { - } & \text { Small surge tanks } \\
\text { - } & \text { Could make use of ORNL design } \\
\text { - } & \text { Can run at low rates } \\
\text { - } & \text { SBW road ready early } \\
\text { - } & \text { Sends bulk waste to WIPP (no transportation or } \\
& \text { disposal cost to INEEL) }\end{array}$ & $\begin{array}{l}\text { Relatively larger number } \\
\text { of shipments (limited to } \\
\text { half-pack shipments to } \\
\text { WIPP) } \\
\text { - Shipping to not begin } \\
\text { until after completion; } \\
\text { requires large interim } \\
\text { storage }\end{array}$ & $\begin{array}{l}\text { - WIR success } \\
\text { - Technical concerns } \\
\text { - Cs desorbtion at elevated temperatures } \\
\text { - Sorbent stability with long-term contact } \\
\text { time with waste }\end{array}$ \\
\hline 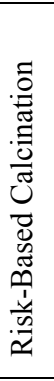 & $\begin{array}{ll}\text { 1. } & \text { Calcination } \\
\text { 2. } & \text { Bin Set storage } \\
\text { 3. } & \text { SBW Calcine treatment in } \\
\text { RHIF or direct canning } \\
\text { facility }\end{array}$ & $\begin{array}{ll}\text { - } & \text { Lowest near term cost } \\
\text { - } & \text { Completes processing by } 2006 \\
\text { - } & \text { Lowest technical risk } \\
\text { - } & \text { Small Surge Tanks } \\
\text { - } & \text { Lowest additional D\&D required (Bin Set } 7 \text { only) } \\
\text { - } & \text { Uses existing facilities } \\
\text { - } & \text { Flat funding } \\
\text { - } & \text { Could direct ship calcine to WIPP }\end{array}$ & $\begin{array}{ll}\text { - } & \text { Highest off-gas releases } \\
\text { - } & \text { Increases new RHIF } \\
& \text { separations processing } \\
& \text { mission by } 25 \% \\
\text { - } & \text { Uses Bin Set } 7 \\
\text { - } & \text { Thermal process }\end{array}$ & $\begin{array}{ll}\text { - } & \text { Requires State to grant the Calciner both } \\
\text { - } & \text { RCRA \& air permit without modifications } \\
\text { - } & \text { Requires new calcine processing facility to } \\
\text { make SBW road-ready } \\
\text { - } \quad \text { Technical Concerns } \\
\text { - Hg mass balance (Si gel adsorbers, scrub } \\
\text { - concentration, calcine fines) } \\
\text { Develop shutdown sequence considering } \\
\text { Hg }\end{array}$ \\
\hline 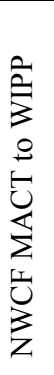 & $\begin{array}{ll}\text { 1. } & \text { Denoxidizer } \\
\text { 2. } & \text { Granulated Activated } \\
\text { Carbon } \\
\text { 3. } \\
\text { 4. } \text { Electrochation } \\
\text { removical Hg } \\
\text { 5. HAW/TRU Handling and } \\
\text { Storage }\end{array}$ & $\begin{array}{ll}\text { - } & \text { Completes processing SBW by } 2012 \text { deadline } \\
\text { - } & \text { Low technical risk } \\
\text { - } & \text { Small surge tanks } \\
\text { - } & \text { Uses existing facility while complying with new } \\
& \text { regulations } \\
\text { - } & \text { Uses calciner to make final waste form } \\
\text { - } & \text { Gets SBW off-site early } \\
\text { - } & \text { Doesn't use Bin Set } 7\end{array}$ & $\begin{array}{ll}\text { - } & \text { Thermal process } \\
\text { - } & \text { RH TRU waste volumes } \\
\text { are the highest } \\
\text { - } \quad \text { Largest number of } \\
\text { shipments } \\
\text { - Cannot begin shipping } \\
\text { until processing is } \\
\text { complete }\end{array}$ & $\begin{array}{ll}\text { - } & \text { State gives Calciner RCRA \& air permit } \\
\text { - } & \text { Thermal Process } \\
\text { - } & \text { WIR success } \\
\text { - } & \text { Exceeds RH-TRU volume limitations at WIPP } \\
\text { - } & \text { Transport of calcine to WIPP } \\
\text { - } & \text { Technical Concerns } \\
\text { - } \quad \text { Calciner layup, preventative } \\
\quad \text { maintenance, startup after 10yr shutdown } \\
\text { - Potential Cl corrosion issue after Hg } \\
\quad \text { removal from scrub }\end{array}$ \\
\hline
\end{tabular}




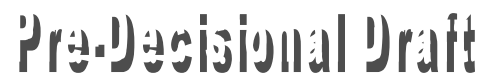

\begin{tabular}{|c|c|c|c|c|}
\hline$\stackrel{\nexists}{\Xi}$ & $\begin{array}{l}\text { Unit Operations/ } \\
\text { Technologies*** }\end{array}$ & Key Benefits & Key Disadvantages & Key Uncertainties \\
\hline 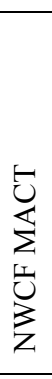 & $\begin{array}{ll}\text { 1. } & \text { Denoxidizer } \\
\text { 2. } & \text { Granulated Activated } \\
& \text { Carbon } \\
\text { 3. } & \text { Calcination } \\
\text { 4. } & \text { Electrochemical Hg } \\
& \text { removal } \\
\text { 5. } & \text { Bin Set storage } \\
\text { 6. } & \text { SBW Calcine treatment in } \\
& \text { RHIF or direct canning } \\
& \text { facility } \\
\end{array}$ & $\begin{array}{ll}\text { - } & \text { Smallest new project cost } \\
\text { - } & \text { Completes processing SBW by } 2012 \text { deadline } \\
\text { - } & \text { Small surge tanks } \\
\text { - } & \text { Uses existing facility while complying with new } \\
\text { - } & \text { regulations } \\
& \text { Could direct ship calcine to WIPP }\end{array}$ & $\begin{array}{ll}\text { - } & \text { Increases new RHIF } \\
\text { separations processing } \\
\text { mission by } 25 \% \\
\text { - } & \text { Uses Bin Set } 7 \\
\text { - } & \text { Thermal process }\end{array}$ & $\begin{array}{ll}\text { - } & \text { State gives Calciner RCRA \& air permit } \\
\text { - } & \text { WIR success } \\
\text { - } & \text { Requires new calcine processing facility to } \\
\text { make SBW road-ready } \\
\text { - Technical Concerns } \\
\text { - Calciner layup, preventative } \\
\text { - } \quad \text { maintenance, startup after } 10 \mathrm{yr} \text { shutdown } \\
\quad \text { removial Cl corrosion issue after Hg } \\
\end{array}$ \\
\hline 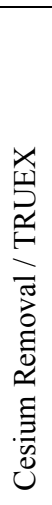 & $\begin{array}{ll}\text { 1. } & \text { Solid / Liquid Separation } \\
\text { 2. } & \text { Ion Exchange } \\
\text { 3. } & \text { TRUEX Extraction } \\
\text { 4. } & \text { Solvent Treatment and } \\
& \text { Disposal } \\
\text { 5. } & \text { Mercury Precipitation } \\
\text { 6. } & \text { Low Activity Waste } \\
& \text { Evaporation } \\
\text { 7. } & \text { Neutralization and Grouting } \\
\text { 8. } & \text { HAW/TRU Evaporation/ } \\
& \text { Destruction } \\
\text { 9. } & \text { HAW/TRU Handling \& } \\
\text { 10. } & \text { Storage } \\
\end{array}$ & $\begin{array}{ll}\text { - } & \text { Most waste is CH-LLW, small RH-TRU and RH- } \\
& \text { LLW } \\
\text { - } & \text { Non-thermal process } \\
\text { - } & \text { Solvent extraction in contact handled area } \\
\text { - } & \text { begin upon generaterion } \\
\text { - } & \text { More than one ion exchange material available } \\
\text { - May be able to ship fast enough to negate need for } \\
\text { - large interim storage (Hanford shipments) } \\
\text { - Can run at low rates } \\
\text { - Could make use of ORNL design }\end{array}$ & $\begin{array}{ll}\text { - } & \text { Higher technical risks } \\
\text { than CsIX } \\
\text { - } & \text { Facility larger than CsIX } \\
& \text { alone } \\
\text { - } & \text { Requires larger surge } \\
\text { tanks to meet } 2012 \\
\text { - } & \text { Processing completes } \\
& \text { after } 2012\end{array}$ & $\begin{array}{l}\text { - WIR success } \\
\text { - Technical concerns } \\
\text { - Desorbing at elevated temperatures } \\
\text { - Sorbent stability with long-term contact } \\
\text { - HEme with waste } \\
\text { - Organics in grout }\end{array}$ \\
\hline 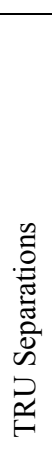 & $\begin{array}{ll}\text { 1. } & \text { Solid / Liquid Separation } \\
\text { 2. } & \text { TRUEX Extraction } \\
\text { 3. } & \text { Solvent Treatment \& } \\
& \text { Disposal } \\
\text { 4. } & \text { Mercury precipitation } \\
\text { 5. } & \text { LAW evaporation } \\
\text { 6. } & \text { Neutralization \& Grouting } \\
\text { 7. } & \text { HAW/TRU Evaporation/ } \\
& \text { Destruction } \\
\text { 8. } & \text { HAW/TRU Handling \& } \\
& \text { Storage }\end{array}$ & $\begin{array}{ll}\text { - } & \text { Small RH-TRU to WIPP } \\
\text { - } & \text { Non-thermal process } \\
\text { Allows shipping of bulk waste to begin upon } \\
\text { generation (LLW disposal) } \\
\text { - May be able to ship fast enough to negate need for } \\
\text { large interim storage (Hanford shipments) } \\
\text { Can run at low rates }\end{array}$ & 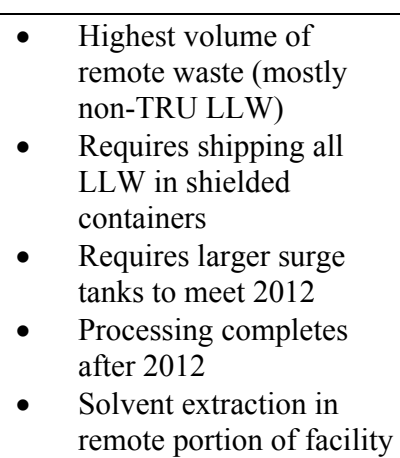 & $\begin{array}{ll} & \text { WIR success } \\
- & \text { Shipping remote drums to Hanford } \\
- & \text { Technical concerns } \\
& \text { - HEDPA destruction success } \\
\text { - } & \text { Organics in grout }\end{array}$ \\
\hline
\end{tabular}




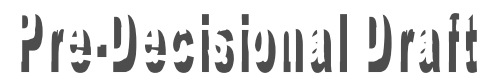

\begin{tabular}{|c|c|c|c|c|}
\hline 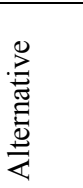 & $\begin{array}{l}\text { Unit Operations/ } \\
\text { Technologies } * * *\end{array}$ & Key Benefits & Key Disadvantages & Key Uncertainties \\
\hline 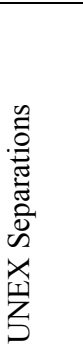 & $\begin{array}{ll}\text { 1. } & \text { Solid / Liquid Separation } \\
\text { 2. UNEX Extraction } \\
\text { 3. }\end{array}$ & $\begin{array}{l}\text { - } \quad \text { Bulk waste is Class A LLW } \\
\text { - } \quad \text { Non-thermal process } \\
\text { Allows shipping of bulk waste to begin upon } \\
\text { generation (LLW disposal) } \\
\text { - May be able to ship fast enough to negate need for } \\
\text { large interim storage (Hanford shipments) } \\
\text { Can run at low rates }\end{array}$ & $\begin{array}{ll}\text { - } & \text { Requires larger surge } \\
\text { tanks to meet } 2012 \\
\text { - } & \text { Processing completes } \\
& \text { after } 2012 \\
\text { - } & \text { Solvent extraction in } \\
& \text { remote portion of facility } \\
\text { - } & \text { Higher technical risks } \\
\text { - } & \text { Higher discovery } \\
& \text { technical risk }\end{array}$ & $\begin{array}{ll}\text { - } & \text { WIR success } \\
\text { - } & \text { WIPP remote volume near maximum } \\
\text { - } & \text { Technical concerns } \\
\text { - } \quad \text { Crystallization success } \\
\text { Organics in grout }\end{array}$ \\
\hline 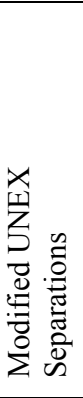 & $\begin{array}{ll}\text { 1. } & \text { Solid / Liquid Separation } \\
\text { 2. } & \text { UNEX Extraction w/o TRU } \\
& \text { extractant } \\
\text { 3. } & \text { Solvent Treatment \& } \\
& \text { Disposal } \\
\text { 4. } & \text { LAW Evaporation } \\
\text { 5. Neutralization \& Grouting } \\
\text { 6. HAW/TRU Evaporation/ } \\
\text { Crystallization } \\
\text { 7. } \\
\text { HAW/TRU Handling \& } \\
\text { Storage }\end{array}$ & $\begin{array}{l}\text { - } \quad \text { Uses solvent extraction to remove gamma from TRU } \\
\text { waste (WIPP becomes } \mathrm{CH} \text { ) } \\
\text { - } \quad \text { Non-thermal process } \\
\text { - } \quad \text { Sends bulk waste to WIPP } \\
\text { - } \quad \text { Can run at low rates }\end{array}$ & $\begin{array}{ll} & \text { Requires larger surge } \\
\text { - } & \text { Panks to meet } 2012 \\
& \text { after } 2012 \\
\text { - } & \text { Solvent extraction in } \\
& \text { remote portion of facility } \\
\text { - } & \text { Higher technical risks } \\
\text { - } & \text { Highest discovery } \\
& \text { technical risk }\end{array}$ & $\begin{array}{l}\text { - WIR success } \\
\text { - WIPP remote volume near maximum } \\
\text { - Technical concerns } \\
\text { - Crystallization success } \\
\text { - Organics in grout }\end{array}$ \\
\hline 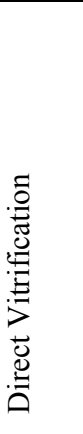 & 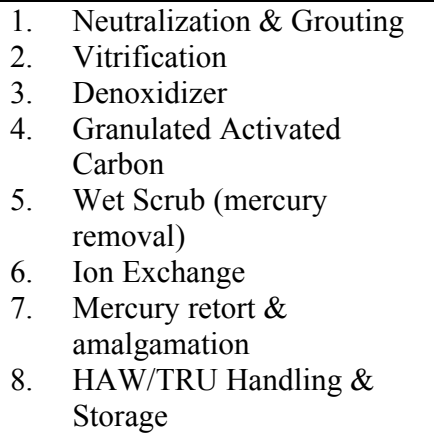 & 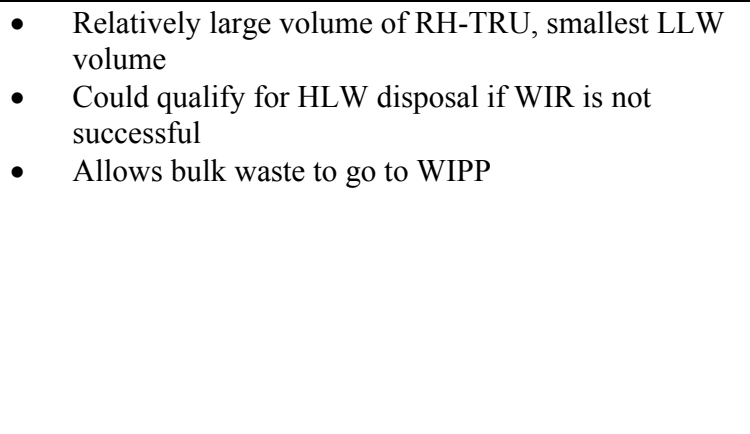 & $\begin{array}{ll}\text { - } & \text { Highest cost } \\
\text { - } & \text { Requires larger surge } \\
\text { - } & \text { Processing to meet } 2012 \\
& \text { after } 2012 \\
\text { - } & \text { Higher technical risks } \\
\text { - } & \text { Cannot begin shipping } \\
& \text { until processing is } \\
\text { - } & \text { Thermal process } \\
\text { - } & \text { Turndown limited }\end{array}$ & $\begin{array}{l}\text { - Need to permit a thermal process } \\
\text { - WIR success } \\
\text { - Near maximum RH-TRU volume limitation at } \\
\text { WIPP } \\
\text { - Technical Concerns } \\
\text { - Melter Operation } \\
\text { - Off-gas Management }\end{array}$ \\
\hline
\end{tabular}

***- All alternatives include both characterization and chemical makeup unit operations 


\section{ACKNOWLEDGMENTS}

The authors could not have compiled this report without the effort of the Core Team, consisting of Rick Adams, Jim Bosley, Jerry Christian, Rod Kimmitt, Jack Law, John McCray, Tom McDonald, Clark Millet, Arlin Olson, Dave Ostby, Brent Palmer, Joe Pruitt, Ed Wagner, Linda Seward, and Buck West. These people set aside their already large workloads to focus on this effort for two months and invested 4000 man-hours. The quality of their effort that supported each element of this report is testimony to their professionalism.

Ken Rueter of Savannah River and Phil McGinnis of Oak Ridge provided valuable insight and validation in their role as peer reviewers. Their positive fingerprints are found in this work and their participation is appreciated. 


\section{CONTENTS}

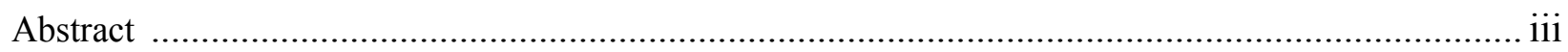

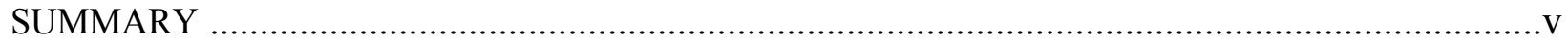

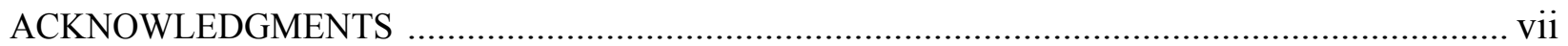

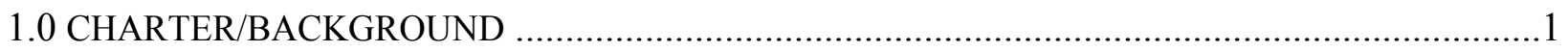

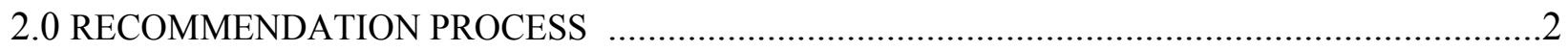

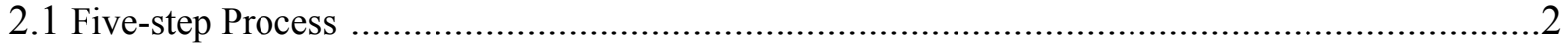

2.2 External Peer Review ........................................................................................

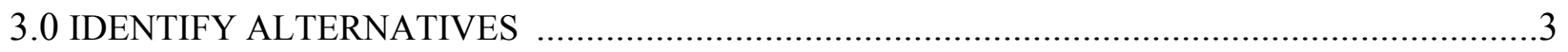

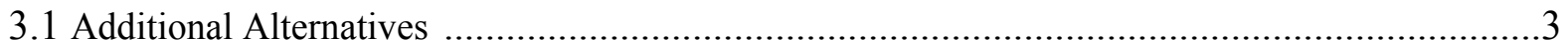

3.2 National Research Council Review and Proposed Alternatives .........................................4

4.0 IDENTIFICATION OF ANALYSIS REQUIREMENTS ...............................................

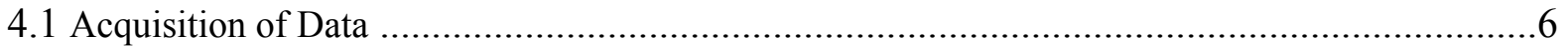

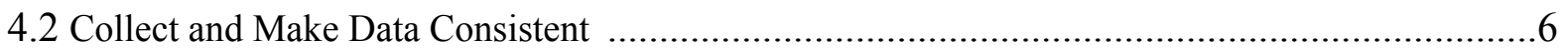

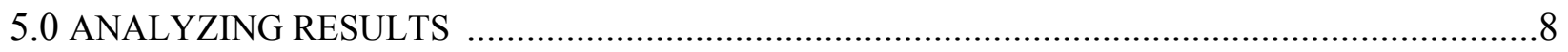

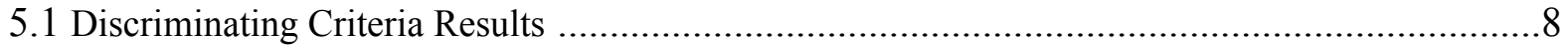

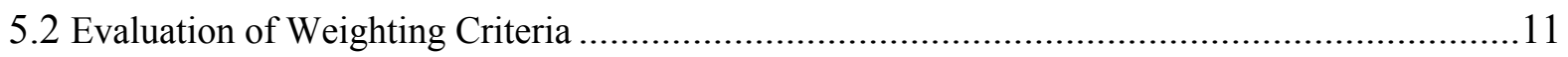

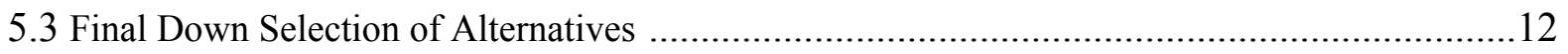

6.0 CONCLUSIONS, RECOMMENDATIONS, AND PATH FORWARD ...................................16

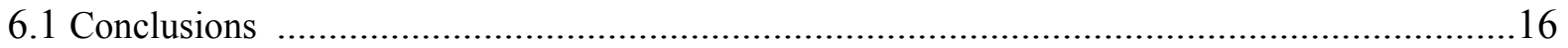

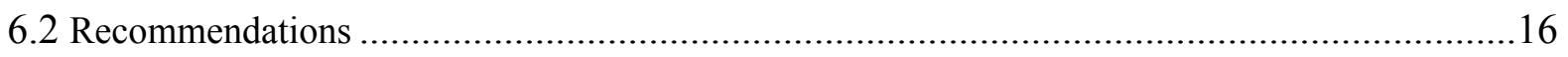

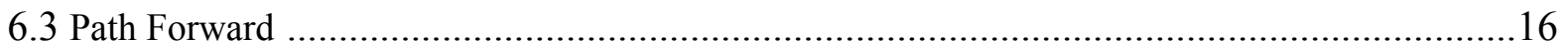

6.4 Analysis of DOE-ID Management Response .................................................... 17

\section{FIGURES}

A. Thermal waste processing alternatives .................................................................... vii

B. Separations waste processing alternatives ................................................................... vii

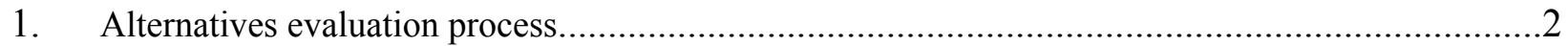

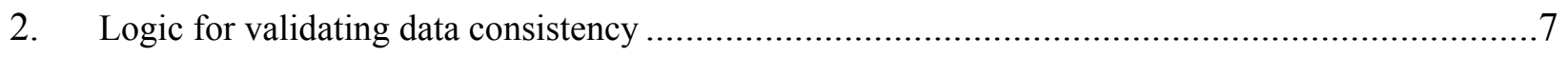

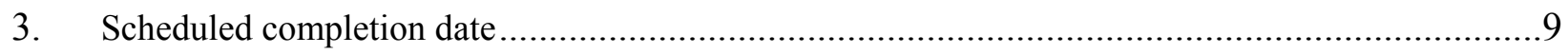

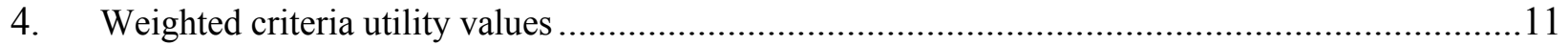


5. “Type of Processing” sensitivity analysis.

\section{TABLES}

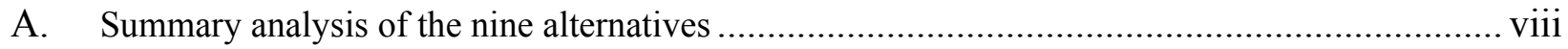

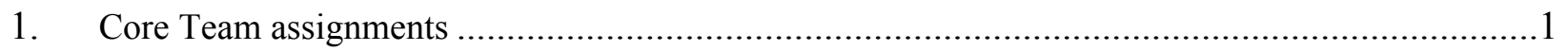

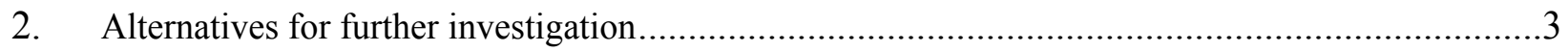

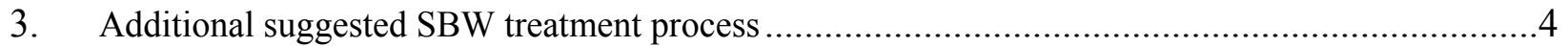

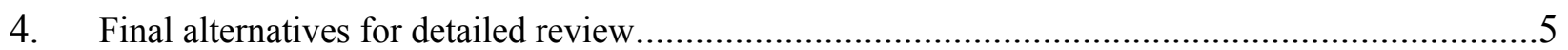

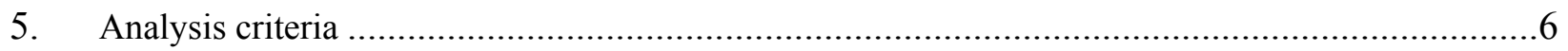

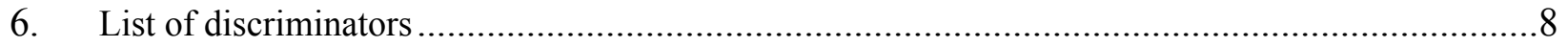

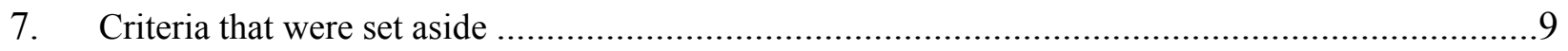

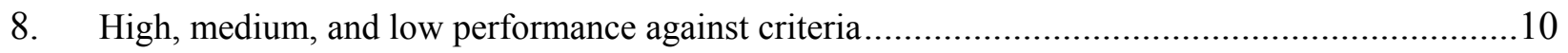

9. Sensitivity results of Monte Carlo evaluation of criteria weighting factors ............................... 12

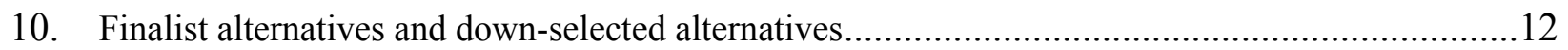

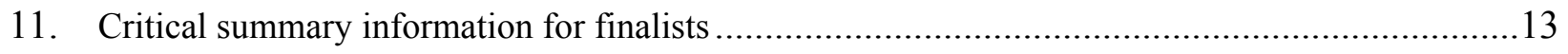




\section{Sodium Bearing Waste Processing Alternatives Analysis}

\subsection{CHARTER/BACKGROUND}

In December 1999, the Department of Energy Idaho Operations Office (DOE-ID) assigned Bechtel BWXT Idaho LLC (BBWI) to evaluate and recommend to DOE-ID a Liquid Waste Processing alternative for consideration in the Idaho High-Level Waste and Facilities Disposition Environmental Impact Statement (HLW \& FD EIS) Record of Decision, and to complete the recommendation by March 15, 2000. In this scope of work, DOE-ID requested that BBWI evaluate the processing of the liquid waste with potential interfaces from the Tank Farm heel solids and the calcine in the bins. By limiting the analysis to these alternatives, the BBWI team focused on finding the best solutions to solve the State of Idaho's number one priority: processing the liquid in the Tank Farm.

A broad-base BBWI Core Team was assembled with expertise that could take advantage of work performed over the past 5-7 years (Appendix A, references). The assigned team members are listed in Table 1. Although additional subject matter experts were consulted when needed, the Core Team members remained constant throughout the analysis period. This report comprises the results of over 4000 man-hours of data collection and analysis.

Table 1. Core Team assignments.

\begin{tabular}{ll}
\hline Name & Responsibility \\
\hline Rick Adams & Cost Estimating \\
Jim Bosley & HLW Program/ES \& H \\
Jerry Christian & Process Chemist \\
Rod Kimmitt & Direct Vitrification \\
Jack Law & Separations \\
John McCray & Grout \\
Tom McDonald & Engineering \\
Clark Millet & Modeling \\
James Murphy & System Analyst \\
Arlin Olson & Tech Lead \\
Dave Ostby & Projects \\
Brent Palmer & HLW Program/Calcination \\
Joe Pruitt & HLW Manager \\
Ed Wagner & Operations \\
Keith Perry & Analysis and Documentation \\
Linda Seward \& Buck West & Facilitators \\
\hline
\end{tabular}

The INEEL has completed several comparative alternative studies that were available to draw upon. Data were extrapolated from the HLW \& FD EIS and additional studies (see Appendix A, references) to perform this analysis. The availability of these data allowed the analysis to be completed in approximately two months. This report presents the alternatives evaluated in a relative manner, the comparable data used to evaluate the alternatives, and decision-based information used to help BBWI management make their recommendation to DOE-ID. 


\subsection{RECOMMENDATION PROCESS}

The process for the development of this recommendation was defined before the Core Team was established. The recommendation process was broken out into several steps that could be independently validated, and two peer reviews were scheduled to facilitate and independently support this validation.

\subsection{Five-step Process}

The BBWI Core Team utilized a five step systematic process displayed in Figure 1. These five steps are: (1) identify alternatives, (2) identify analysis requirements, (3) collect and make data consistent among alternatives, (4) analyze results, and (5) document and communicate results. Figure 1 shows the timeline in which these steps were performed as well as the timing of the external peer reviews, discussed below. Steps 1 through 5 are discussed respectively in Sections 3.0 through Section 7.0.

\begin{tabular}{|c|cccc}
\multirow{1}{*}{ Step 1 } & \multicolumn{4}{c}{ Core Team Full-time involvement } \\
\cline { 2 - 5 } & $\begin{array}{c}\text { Step 2 } \\
\text { Identify }\end{array}$ & $\begin{array}{c}\text { Step 3 } \\
\text { Collect and }\end{array}$ & Step 4 & Step 5 \\
Identify & $\begin{array}{c}\text { analysis } \\
\text { make data }\end{array}$ & $\begin{array}{c}\text { Analyze } \\
\text { data }\end{array}$ & $\begin{array}{c}\text { Document and } \\
\text { communicate }\end{array}$ \\
\hline alternatives & requirements & consistent & $2 / 14-2 / 21$ & $2 / 17-3 / 15$ \\
\hline $11 / 15-12 / 20$ & $1 / 3-1 / 11$ & $1 / 11-2 / 14$ & $2 / 14-1$ & $\uparrow$ \\
& & $\uparrow$ & & Peer Review 2 \\
& & Peer Review 1 & $2 / 28-3 / 1$
\end{tabular}

Figure 1. Alternatives evaluation process.

\subsection{External Peer Review}

Prior to the official kickoff of this effort, DOE-ID and INEEL HLW management determined the need for an external peer review to validate the effort invested and data collected by the Core Team. The review team consisted of Ken Rueter from the Westinghouse Savannah River Company, who serves as the project manager for the Salt Disposition Analysis Team, and Phil McGinnis from Oak Ridge National Laboratory (ORNL), who serves as the Pretreatment manager for the Tanks Focus Area. Both have unquestioned backgrounds and expertise in dealing with HLW programs and systems engineering processes, giving them an understanding of both the analysis and the actual data associated with the analysis.

The review team was chartered to validate both the recommendation process that the Core Team employed as well as the data gathered to support the recommendation. Their review was thorough, and apart from a few additions and requests detailed below, the review team supported both the process and the validity of the data. The key comments and requests, as well as the Core Team's responses to the input, are summarized in Appendix B, with the reviewers' official comments appearing in Appendix B.1. 


\subsection{IDENTIFY ALTERNATIVES}

Two facilitated meetings were held to identify alternatives for consideration in this analysis. The first meeting focused on defining alternatives involving continued use of the Calciner. The list of participants and their report are available in Appendix C. The second meeting focused on new technology and facility processes that could be used to convert the sodium bearing waste (SBW) to a final waste form. The list of participants and their report are available in Appendix D.

Each alternative development meeting began with an explanation of the requirements governing alternative definition. Overall, there were three guiding requirements at this stage of development: (1) all alternatives must be able to remove the SBW from the Tank Farm by 2012, (2) all alternatives must fit into the envelope defined by the EIS, and (3) all alternatives must be technically feasible.

The Calciner alternatives meeting concluded that two alternatives be further investigated and five alternatives screened out from further evaluation. The non-Calciner alternatives meeting concluded with 7 alternatives for further investigation and one alternative screened out from further evaluation.

\subsection{Additional Alternatives}

A modification of the previously screened out Full Separations alternative was added back onto the alternative evaluation list during the first External Peer Review. Early in the analysis, it was identified that since Sr-90 is a beta emitter without a strong gamma daughter product, strontium itself would not necessitate remote handling of the waste and shielding issues would not apply. Therefore, Full Separations was introduced without strontium removal and was named the CsIX/TRUEX alternative.

Members of the Core Team added a hybrid alternative that was a slight modification to the MACT Calciner alternative following the first peer review. The proposed alternative would directly package the calcine made from sodium-bearing waste (SBW) into containers for shipment to the Waste Isolation Pilot Plant (WIPP) at the earliest possible time. It was assumed that this alternative was bounded by a combination of the HLW EIS (calcination) and the WIPP EIS (transportation and waste acceptance and disposal). The alternative was included along with the other two Calciner alternatives in the final analysis. All of the alternatives are shown in Table 2.

Table 2. Alternatives for further investigation.

\begin{tabular}{ll}
\hline Calciner Alternatives & Non-Calciner Alternatives \\
\hline Risk-Based Calcination & UNEX \\
Maximum Achievable Control & Modified UNEX \\
Technology (MACT) Calcination & \\
MACT to WIPP Calcinations (Hybrid & Cesium lon Exchange (CsIX) \\
added by Core Team) & TRU Seps \\
& Direct Vitrification \\
& CsIX/TRUEX (Hybrid added by Core Team)
\end{tabular}

\subsection{National Research Council Review and Proposed Alternatives}

Several potential processes for treating the SBW for disposal were suggested by the National Research Council's review of the technical alternatives under consideration by the DOE for future waste 
management operations at Idaho National Engineering and Environmental Laboratory (INEEL). These are listed in their report, Alternative High-Level Waste Treatments at the Idaho National Engineering and Environmental Laboratory, ISBN 0-309-06628-X, 1999. An additional process conceived by INEEL researchers has also been suggested. These treatment schemes were compared to the alternatives being evaluated in this study. The suggested processes and comparable alternatives are listed in Table 3.

Table 3. Additional suggested SBW treatment process.

\begin{tabular}{ll}
\hline Suggested SBW Treatment Process & Comparison Process \\
\hline 1. Acid Side Direct Solidification & MACT to WIPP \\
2. Acid Destruction, Neutralization, and Direct Evaporation & MACT to WIPP \\
3. Acid Destruction, Neutralization, Solid-Liquid Separation and & TRU Separations \\
Solidification & \\
4. Acid Destruction, Alkaline Leaching, Solid-Liquid Separation and & TRU Separations \\
$\quad$ Solidification & \\
5. TRU Separation by Lanthanum Fluoride Precipitation & TRU Separations \\
6. Conversion to Calcine and Storage Apart from HLW Calcine & Risk-based or MACT \\
7. Fractional Evaporation/Crystallization & TRU Separations \\
\hline
\end{tabular}

A more detailed analysis of these suggested processes is available in Appendix F. In summary, these proposed processing schemes were screened from further evaluation for the following reasons:

- Processes 1 and 2 require capital expenditures for plant and equipment and generate essentially the same types and quantities of waste as operating the existing Calciner, with or without a MACT upgrade.

- Processes 3, 4, and 5 compare to the TRU Separations alternative. Each was dismissed on the basis of previous evaluation, increased complexity, uncertainties in technical basis, and/or increased final waste volumes in the comparison.

- Process 6 is basically equivalent in strategy and processing to the Risk-based and MACT alternatives, and differs from the MACT-WIPP alternative only in that the calcine is being stored for phase II processing. Therefore, this alternative was included in the analysis.

- Process 7 was introduced late into the evaluation and was not evaluated with the main nine alternatives listed above. The potential alternative was subsequently reviewed qualitatively, as any other new alternatives would be, to understand the potential unique advantages and disadvantages. The screening criteria will be used to determine if further quantitative evaluation is required. For Process 7, the technical unknowns were significant enough to place the completion timing no earlier than about 2015, the facility and equipment needs are significant enough to require a new shielded facility with new equipment capable of performing the operations under abnormal conditions, and the uncertainty associated with the qualification of the waste forms caused this alternative to be screened out. If BBWI or DOE-ID management change the basic requirements or rules of analysis, the alternatives analysis will need to be re-evaluated against the new requirements and rules prior to making final conclusions.

The list of the final alternatives along with those alternatives screened from further review in this evaluation is shown in Table 4. 
Table 4. Final alternatives for detailed review.

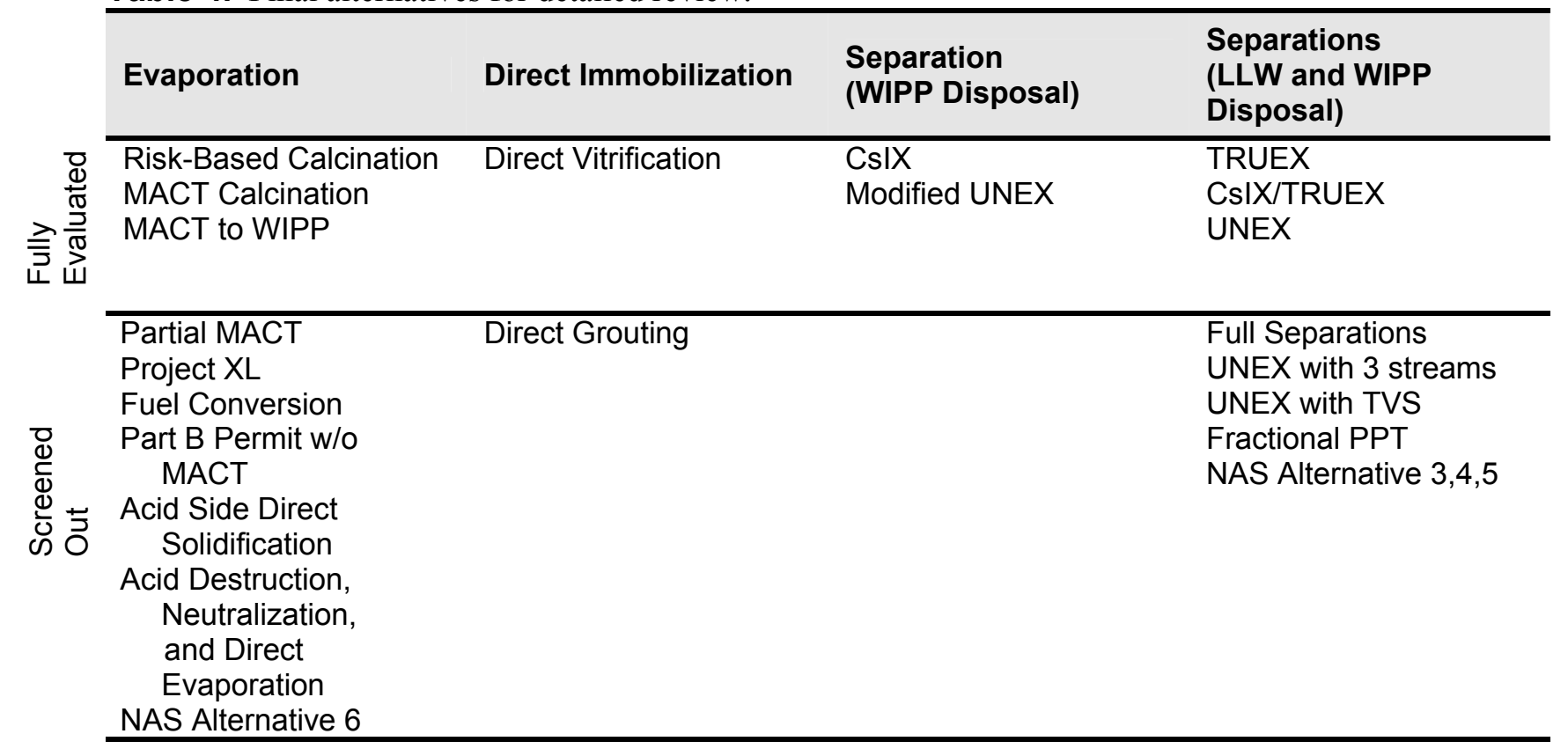




\subsection{IDENTIFICATION OF ANALYSIS REQUIREMENTS}

In any recommendation process, it is critical to have a common set of rules or requirements. This allows choices among alternatives to be equitable since the comparison weighs the various criteria against a common set of requirements. For the BBWI recommendation, the requirements, rules for analysis, and goals were set early in the activity and reviewed with HLW management at BBWI and DOE-ID. The requirements, rules, and goals are available in Appendix H. It should be noted that the list provided was the result of an initial development meeting and subsequent lessons-learned iterations.

As the goals defined the desirable qualities of the alternatives, the criteria endeavored to capture the level of "goodness" of alternatives using defined measures of effectiveness (MOEs). Each criterion was defined with an associated MOE such that it was clear what constituted good versus poor performance. Each criterion is defined in detail in Appendix I, Criteria Definitions, while Table 5 shows the criteria and their categories (see Section 5.1)

Table 5. Analysis criteria.

\begin{tabular}{|c|c|c|}
\hline Cost & Technical Feasibility & Public Acceptance \\
\hline Total INEEL Cost & $\begin{array}{l}\text { Cumulative technology } \\
\text { risk } \\
\text { Discovery risk }\end{array}$ & $\begin{array}{l}\text { HAW disposal used } \\
\text { Date road-ready }\end{array}$ \\
\hline Schedule & Off-gas performance & Surge tank size \\
\hline Date SBW complete & $\begin{array}{l}\text { Degree of waste } \\
\text { handling difficulty }\end{array}$ & $\begin{array}{l}\text { Type of processing } \\
\text { Number of shinments }\end{array}$ \\
\hline Ease of D\&D & Programmatic Risk & \\
\hline Facility waste generated & $\begin{array}{l}\text { Ability to obtain funding } \\
\text { - through } 2012 \\
\text { Total TPC required }\end{array}$ & \\
\hline
\end{tabular}

\subsection{Acquisition of Data}

Having developed the potential discriminating criteria for the process, it was then necessary to identify what information was known and not known for a given alternative. Although data were available for collection and assimilation, generation of additional information was necessary to fill gaps in the existing data. A data gathering strategy was developed, since much of the data built upon other pieces of information to form a cohesive whole. For example, accurate operating costs could not be developed without the waste processing schedule information or an understanding of the equipment that would be designed and built for a given alternative. A Strategy Flowchart in Appendix J shows the interface logic used to drive the scheduling of the data gathering activities throughout the data collection period.

As the team developed the criteria data, it was necessary to carefully document both the bases and assumptions leading to their development. For example, team members had to manipulate an available feasibility study to meet the needs for a given alternative. An Engineered Design File (EDF) was used to reference the changes as well as the assumptions used for the facility costing. Such assumptions were captured in backup files for each criterion. Appendix I describes each of the criteria shown in Table 5 and the general steps used to generate the data.

\subsection{Collect and Make Data Consistent}

Iteration became an important factor among team members to ensure the data generated for comparison had an equivalent basis. The team created several checkpoints where data were compared to assure that 
they were based on the same assumptions and foundation. Since the data were being collected and developed by several people in parallel, some normalization was expected. In addition, as the peer reviewers examined the data and noted some key assumptions, the team decided to take extra care in validating the assumptions and making sure they were promulgated through all alternatives. Figure 2 demonstrates the simple logic used to validate the consistency of the basis and assumptions behind the data.

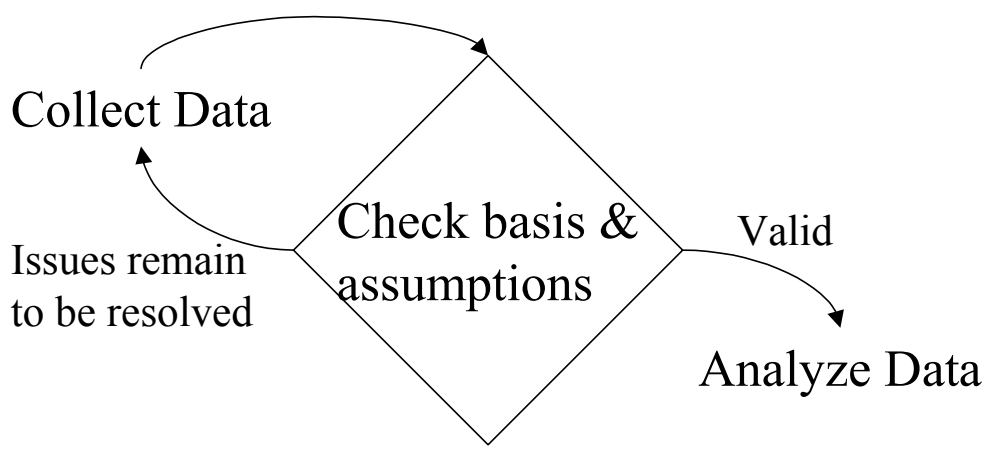

Figure 2. Logic for validating data consistency. 


\subsection{ANALYZING RESULTS}

Alternatives from the analysis were evaluated using criteria specific results. The objective of the established criteria was to provide comparable discrimination of the alternatives. Many criteria were evaluated for potential discrimination among the alternatives.

\subsection{Discriminating Criteria Results}

Not all the criteria evaluated provided useful comparative analysis data. Some of the criteria were better measured by another criterion or did not offer discrimination at all. To improve the understanding of the differences among alternatives, the criteria and associated data that did not provide discrimination were set aside. Table 6 lists the criteria found to discriminate among the alternatives. Table 7 lists the criteria that were set aside and shows the criteria heading where they are measured.

Table 6. List of discriminators.

\begin{tabular}{|c|c|}
\hline Discriminators & \\
\hline $\begin{array}{l}\text { Cost } \\
\text { - Total INEEL cost } \\
\text { Schedule } \\
\text { - Calculated } \\
\quad \text { completion date } \\
\quad \text { (900,000 gallons) } \\
\text { Technical Feasibility } \\
\text { - Cumulative } \\
\text { technology risk } \\
\text { - Discovery risk } \\
\text { - Off-gas } \\
\text { performance } \\
\text { - Waste handling } \\
\text { difficulty }\end{array}$ & $\begin{array}{l}\text { Public Acceptance } \\
\text { - } \quad \text { HAW/WIPP capacity } \\
\text { - } \quad \text { Date road-ready } \\
\text { - } \quad \text { Surge tank size to } \\
\text { include NGLW } \\
\text { - } \quad \text { Type of processing } \\
\text { - } \quad \text { Number of shipments } \\
\text { Programmatic Risk } \\
\text { - } \quad \text { Ability to obtain funding } \\
\text { - TPC total } \\
\text { Ease of D\&D } \\
\text { - } \quad \text { Minimize waste } \\
\quad \text { generation }\end{array}$ \\
\hline
\end{tabular}


Table 7. Criteria that were set aside.

\begin{tabular}{|c|c|}
\hline \multicolumn{2}{|c|}{ Non-discriminating or repetitive criteria } \\
\hline $\begin{array}{ll}\text { Cost } \\
\text { - } & \text { Tech } \\
& \text { development } \\
\text { - } & \text { TPC } \\
\text { - } & \text { Operation cost } \\
\text { - } & \text { Interim storage } \\
\text { - } & \text { Disposal Cost } \\
\text { Schedule } \\
\text { - } \quad \text { Date newly } \\
\quad \text { generated waste } \\
\quad \text { completed } \\
\text { - } \quad \text { Time to title } \\
\\
\text { design }\end{array}$ & $\begin{array}{l}\text { Public Acceptance } \\
\text { - } \quad \text { LAW disposal needed } \\
\text { - } \quad \% \text { SBW road-ready } \\
\text { Programmatic Risk } \\
\text { - } \quad \text { Ability to obtain funding } \\
\text { - through } 2012 \\
\text { - } \quad \text { Maximum growth of } \\
\quad \text { budget needs cost } \\
\text { Technical Feasibility } \\
\text { - } \quad \text { Radiation Level of } \\
\quad \text { output (of WAC limit) }\end{array}$ \\
\hline
\end{tabular}

The data collected for this analysis contain uncertainty. The Core Team did not want to allow small differences that were within the range of analysis error to be the basis for discrimination. To avoid these types of comparisons, the criteria data were categorized into three comparable states: high, moderate, and low performance. For example, Figure 3 shows the scheduled completion date for the liquid treatment of the Tank Farm. As displayed in the graph, only three levels of relative performance are identified; high for finishing significantly early for Risk-Based, moderate for on-time completion for CsIX, MACT, and MACT to WIPP, and low for the alternatives finishing a few years after 2012. Appendix K, Results Evaluation and Normalization, provides the numerical results and division of the data into the performance levels for all the criteria; Table 8 summarizes the low, moderate, and high performance for each criterion across each candidate alternative. These performance data were normalized such that "high" was always good and "low" was always less favorable.

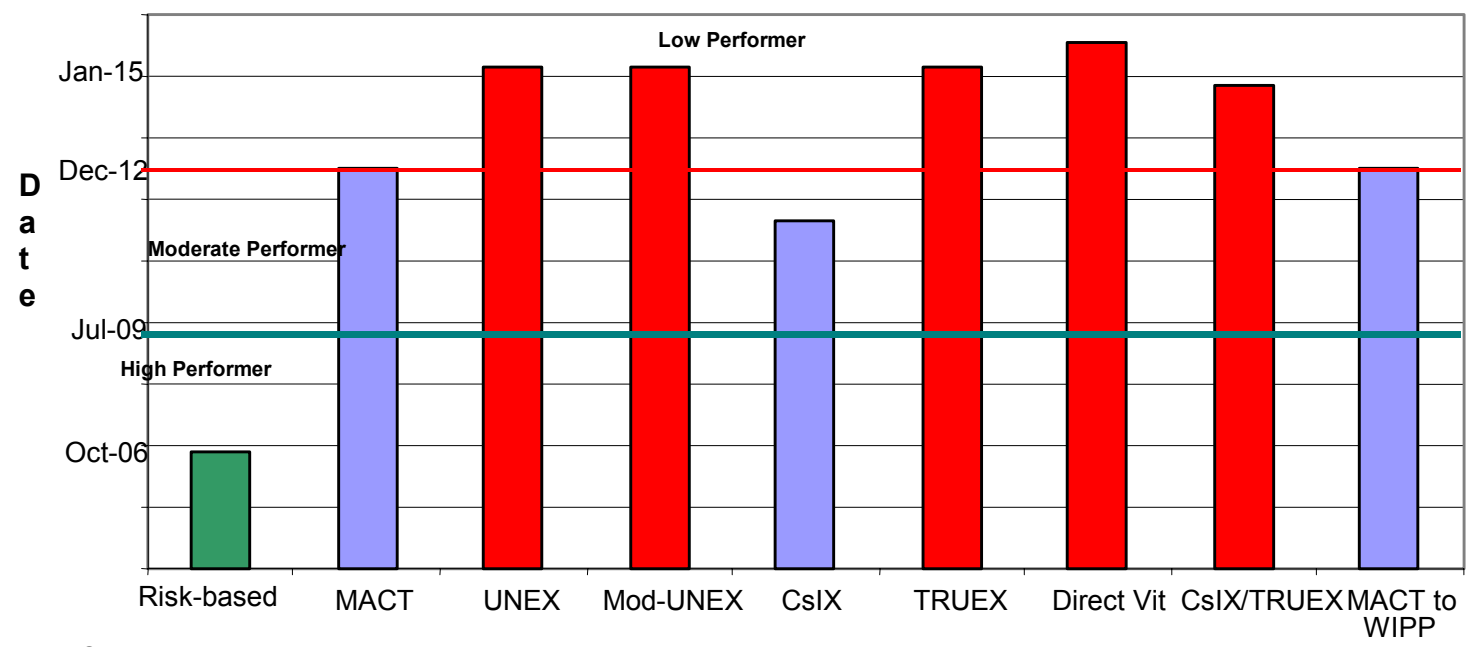

Figure 3. Scheduled completion date. 
Table 8. High, medium, and low performance against criteria.

Discriminating Criteria

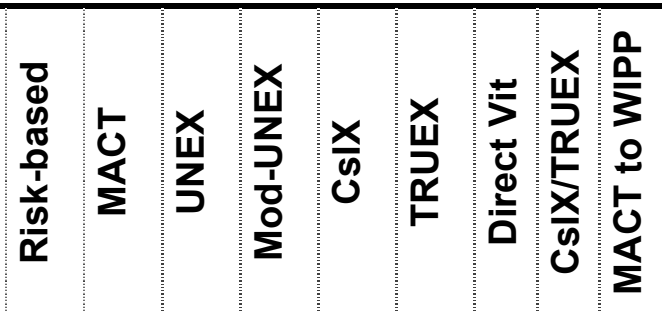

Cost

Total INEEL Cost

Schedule

Calculated completion date $(900,000$ gal. $)$

Technical Feasibility

Cumulative Technical Risk

Discovery Risk

Off-gas Performance

Waste Handling Difficulty

Public Acceptance

HAW/WIPP Capacity Use

Date road ready

Surge tank size to include NGLW

Type of Processing

Number of Shipments

Programmatic Risk

Ability to obtain funding

TPC total

\begin{tabular}{|l|l|l|l|l|l|l|l|l|}
\hline$M$ & $L$ & $M$ & $M$ & $H$ & $M$ & $L$ & $M$ & $H$ \\
\hline
\end{tabular}

\begin{tabular}{ll|l|l|l|l|l|l|l|l|}
\hline$H$ & $M$ & $L$ & $L$ & $M$ & $L$ & $L$ & $L$ & $M$
\end{tabular}

\begin{tabular}{|l|l|l|l|l|l|l|l|l|}
\hline$H$ & $M$ & $L$ & $L$ & $M$ & $L$ & $L$ & $L$ & $M$ \\
\hline
\end{tabular}

$\begin{array}{llllllllllll}H & M & L & L & M & L & M & L & M\end{array}$

\begin{tabular}{llllllllllllll}
\hline $\mathrm{L}$ & $\mathrm{H}$ & $\mathrm{H}$ & $\mathrm{H}$ & $\mathrm{H}$ & $\mathrm{H}$ & $\mathrm{H}$ & $\mathrm{H}$ & $\mathrm{H}$
\end{tabular}

\begin{tabular}{llllllllllll}
\hline & $H$ & $H$ & $H$ & $M$ & $M$ & $L$ & $H$ & $H$ & $M$
\end{tabular}

Ease of D\&D

Minimize waste generation

\begin{tabular}{|l|l|l|l|l|l|l|l|l|}
\hline$H$ & $H$ & $L$ & $M$ & $M$ & $M$ & $L$ & $M$ & $H$ \\
\hline
\end{tabular}

Appendix K.1 contains the data supporting Table 8 . 


\subsection{Evaluation of Weighting Criteria}

The H-M-L performance data shown in Table 8 were used to compare the relative performance of the alternatives against the criteria by the use of a multi-attribute decision analysis using various weighting factors. The first case was evaluated using equal weights for each of the fourteen discriminators. A second case was evaluated using the average of each of the Core Team member's weights. Figure 4 shows both of the results. However, weighting factors are subjective; therefore, a sensitivity study was performed on the significance of the weighting factors in ranking the best alternatives.

A Monte Carlo sensitivity analysis was used to measure the effect of changing weighting factors across a broad range. The analysis consisted of using a software package (Crystal Ball) to vary the weighting of each criterion independently in a normal distribution of three standard deviations above and below the Core Team's average weights. All nine alternatives were ranked $1^{\text {st }}$ through $9^{\text {th }}$ in each case and those results were tallied for 10,000 cases. If the results show a random distribution of alternatives across the placing, i.e. $1^{\text {st }}$ through $9^{\text {th }}$, this would mean that the results are sensitive to criteria weighting. However, the analysis revealed that $99.6 \%$ of the time, the same three alternatives; Risk-based, CsIX, and MACT to WIPP, are the top performers, meaning that the results are insensitive to reasonable changes in weighting factors. Table 9 shows the percentage of total number cases that each alternative ranked in a particular position.

Weighting Factor Analysis

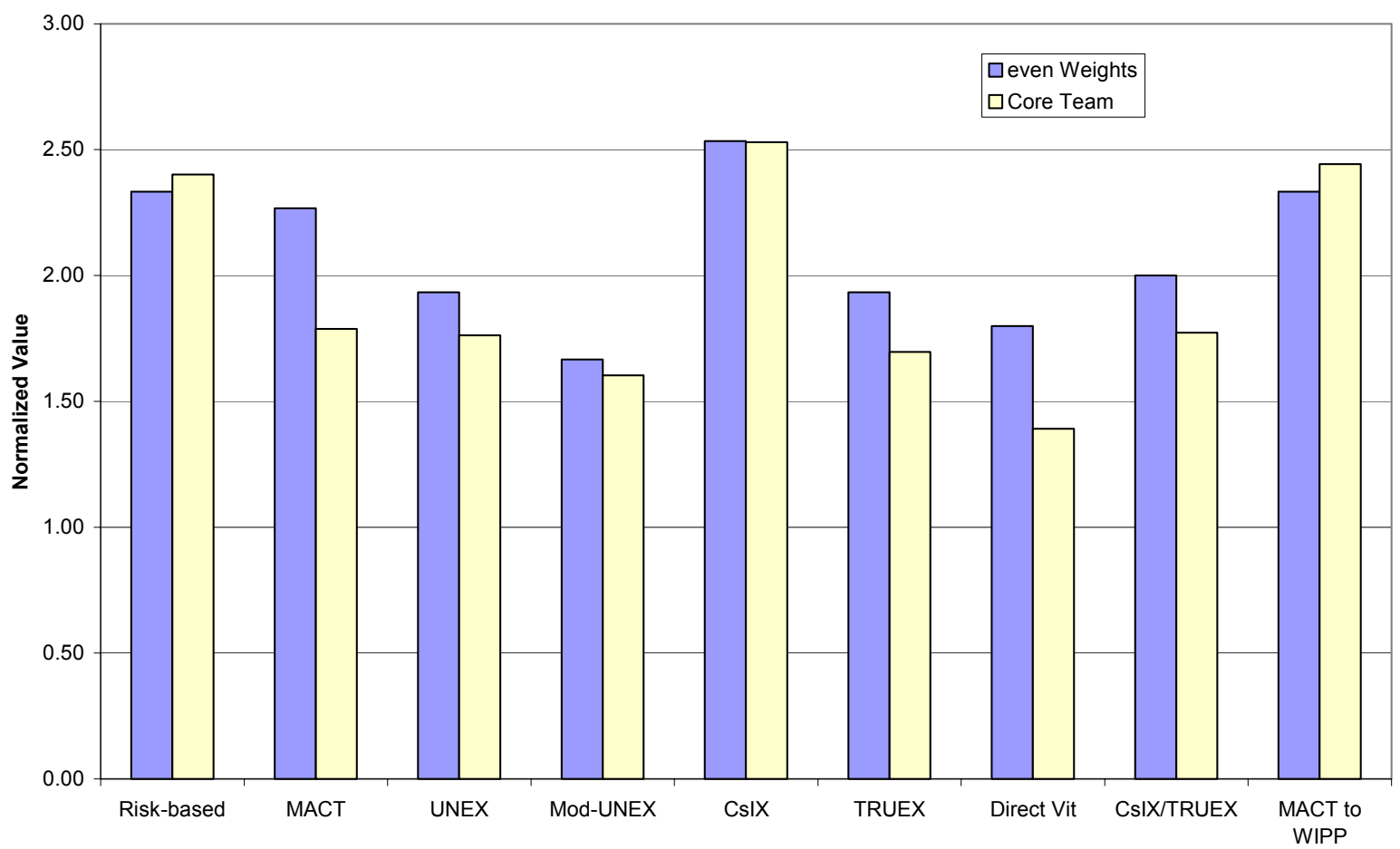

Figure 4. Weighted criteria utility values. 
Table 9. Sensitivity results of Monte Carlo evaluation of criteria weighting factors.

\begin{tabular}{|c|c|c|c|c|c|c|c|c|c|}
\hline Rank & $\begin{array}{l}\text { Risk- } \\
\text { based }\end{array}$ & MACT & UNEX & $\begin{array}{l}\text { Mod- } \\
\text { UNEX }\end{array}$ & CsIX & TRUEX & $\begin{array}{l}\text { Direct } \\
\text { Vit }\end{array}$ & $\begin{array}{l}\text { CsIX/TRU } \\
\text { EX }\end{array}$ & $\begin{array}{l}\text { MACT to } \\
\text { WIPP }\end{array}$ \\
\hline 1 & $42.3 \%$ & $0.0 \%$ & $0.0 \%$ & $0.0 \%$ & $53.4 \%$ & $0.0 \%$ & $0.0 \%$ & $0.0 \%$ & $4.4 \%$ \\
\hline 2 & $17.5 \%$ & $0.1 \%$ & $0.0 \%$ & $0.0 \%$ & $39.0 \%$ & $0.0 \%$ & $0.0 \%$ & $0.0 \%$ & $43.4 \%$ \\
\hline 3 & $40.3 \%$ & $0.3 \%$ & $0.0 \%$ & $0.0 \%$ & $7.6 \%$ & $0.0 \%$ & $0.0 \%$ & $0.0 \%$ & $51.9 \%$ \\
\hline 4 & $0.0 \%$ & $87.4 \%$ & $0.0 \%$ & $0.0 \%$ & $0.0 \%$ & $4.2 \%$ & $0.0 \%$ & $8.1 \%$ & $0.4 \%$ \\
\hline 5 & $0.0 \%$ & $2.6 \%$ & $4.5 \%$ & $0.0 \%$ & $0.0 \%$ & $29.0 \%$ & $0.0 \%$ & $63.9 \%$ & $0.0 \%$ \\
\hline 6 & $0.0 \%$ & $2.9 \%$ & $51.2 \%$ & $0.1 \%$ & $0.0 \%$ & $17.7 \%$ & $0.0 \%$ & $28.1 \%$ & $0.0 \%$ \\
\hline 7 & $0.0 \%$ & $3.9 \%$ & $44.3 \%$ & $6.5 \%$ & $0.0 \%$ & $45.1 \%$ & $0.3 \%$ & $0.0 \%$ & $0.0 \%$ \\
\hline 8 & $0.0 \%$ & $2.9 \%$ & $0.0 \%$ & $92.1 \%$ & $0.0 \%$ & $3.9 \%$ & $1.1 \%$ & $0.0 \%$ & $0.0 \%$ \\
\hline 9 & $0.0 \%$ & $0.0 \%$ & $0.0 \%$ & $1.3 \%$ & $0.0 \%$ & $0.1 \%$ & $98.6 \%$ & $0.0 \%$ & $0.0 \%$ \\
\hline top third & $100.0 \%$ & $0.4 \%$ & $0.0 \%$ & $0.0 \%$ & o $100.0 \%$ & $0.0 \%$ & $0.0 \%$ & $0.0 \%$ & $99.6 \%$ \\
\hline bottom $2 / 3$ & $0.0 \%$ & $99.6 \%$ & $100.0 \%$ & \% $100.0 \%$ & $0.0 \%$ & $100.0 \%$ & $100.0 \%$ & $100.0 \%$ & $0.4 \%$ \\
\hline
\end{tabular}

These data are also shown graphically in Appendix L.

\subsection{Final Down Selection of Alternatives}

The results of the performance comparisons divided the top three performing alternatives from the remaining alternatives so profoundly that the down selection is obvious. The evaluation results demonstrate that weighting factors were useful in obtaining the top performers; however, the weighting analysis did not provide enough discrimination to support a final selection from among the top three alternatives. Table 10 shows the down selection line for the alternatives evaluated.

Table 10. Finalist alternatives and down-selected alternatives.

\begin{tabular}{|c|c|c|c|c|}
\hline & Evaporation & $\begin{array}{l}\text { Direct } \\
\text { Immobilization }\end{array}$ & $\begin{array}{l}\text { Separation (WIPP } \\
\text { Disposal) }\end{array}$ & $\begin{array}{l}\text { Separations (LLW and } \\
\text { WIPP Disposal) }\end{array}$ \\
\hline 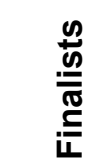 & $\begin{array}{l}\text { - } \text { Risk-Based Calcination } \\
\text { - } \text { MACT to WIPP }\end{array}$ & None & - $\mathrm{CsIX}$ & None \\
\hline 兽 & - MACT Calcination & $\begin{array}{ll}\text { - } & \text { Direct } \\
\text { Vitrification }\end{array}$ & $\begin{array}{l}\text { - } \quad \text { Modified } \\
\text { UNEX }\end{array}$ & $\begin{array}{ll}\text { - } & \text { TRUEX } \\
\text { - } & \text { CsIX/TRUEX } \\
\text { - } & \text { UNEX }\end{array}$ \\
\hline
\end{tabular}

To select the best alternative among the finalists, the Core Team identified the key uncertainties that, if additional information were available, could provide the basis for a single, final selection. These uncertainties could lead to either a positive or negative effect on that final selection. For both programmatic and technical uncertainties, additional data are needed to ensure the best decision in the time available. Table 11 shows the top three alternatives with the final selection considerations for each alternative.

The first bulleted area of concern discussed in Table 11 for the Risk-based calcination alternative describes the uncertainty that exists with obtaining a permit to operate the calciner without the necessary upgrade to meet the MACT requirements. If this uncertainty becomes a reality, the Risk-based alternative is not viable, no matter how well the alternative scored in the multi-attribute decision analysis. The Core 
Team had identified this assumption as high risk. In a follow-on BBWI management briefing of the alternative results, it was confirmed that the uncertainty to operate the calciner without upgrades to empty the Tank Farm was indeed very likely to make the Risk-based alternative non-viable.

Both MACT to WIPP and the CsIX alternatives have favorable performance results and require additional information down-select further. These data that are needed will further evaluate the effect of the key uncertainties on the alternative's performance.

Table 11. Critical summary information for finalists.

\section{RISK BASED CALCINATION}

- Negotiate an interim status permit without upgrades

- Calcine as soon as possible

- Segregate calcine in Bin 7

\begin{tabular}{|c|c|}
\hline $\begin{array}{l}\text { Benefits } \\
\text { - } \quad \text { Finishes } \\
\text { Tank Farm } \\
\text { by } 2006 \\
\text { - } \quad \text { Keeps } \\
\text { funding flat } \\
\text { - } \quad \text { Lowest } \\
\text { technical risk }\end{array}$ & $\begin{array}{l}\text { Critical } \\
\text { Points of } \\
\text { Decision } \\
\text { - Gets the } \\
\text { job done } \\
\text { the } \\
\text { quickest }\end{array}$ \\
\hline
\end{tabular}

\section{Areas of Concern}

- Get State to give calcine permit without modifications

- Thermal Process

- Hg mass balance (up the stack, Si gel absorbers, scrub concentration)

- Develop shutdown sequence considering $\mathrm{Hg}$

- Requires new calcine processing facility to make road-ready

\section{MACT TO WIPP}

- Do MACT upgrade and include canister loading, remote interim storage, and direct shipping to WIPP for disposal
Uses existing facility to get the waste to off-site disposal in compliance
- Get waste to WIPP with minimal new facilities
- Fitting in WIPP's capacity for RH-TRU (limited)

- Large number of shipments

- Calciner layup, preventative maintenance, startup after 10yr shutdown

- Potential $\mathrm{Cl}$ corrosion issue after $\mathrm{Hg}$ removal from scrub

- Transport of calcine to WIPP

- Technical concerns around desorbing at elevated temperatures

\section{WIPP}

with a nonthermal treatment process

- $\quad$ Ship TRU to WIPP, LLW to Hanford

During the analysis of alternatives, the need for new liquid waste storage tanks and heel solids processing was identified. Two other issues, waste incidental to reprocessing and solids/liquid characterization, were discussed that are important to the overall decision-making process, but were determined to not be strong discriminating criteria for the alternatives. These items are discussed below. 
Liquid Waste Storage Tanks

Liquid waste storage tanks are needed for two main purposes in the alternatives. First, surge tanks are needed in any alternative to de-couple the preparation of feed from the processing facility. The volume of this surge capacity is process specific and will be defined by the process design. Costs for this surge was included in each process estimate and was not considered further during evaluation of alternatives. Second, a more significant concern is the new tank farm volume required to: 1 . Store newly generated liquid waste prior to 2012 after other compliant tankage is filled; 2. Store SBW transferred from the existing Tank Farm by December 31, 2012 to meet the requirements of the NON Consent Order; and 3. Store newly generated liquid waste after 2012 until a new treatment facility is available. To determine the required volume for each case, the assumptions and liquid waste generation rates from the INTEC Waste Minimization Plan were used. The alternatives which completed processing the SBW by 2012 (calciner options and CsIX) required only modest (100,000 to 300,000 gallons) storage volumes since they basically only had to store newly generated waste from the time they finished processing existing waste until a new treatment process for calcine came on line (assumed to be 2020). The other processes, which did not process the waste by 2012, all required approximately 1,000,000 gallons capacity to meet Requirement 2. Options, other than building new tanks, for providing the required storage volume were investigated previously (ICPP Tank Farm Systems Analysis, WINCO-1192, January 1994). When the preferred alternative is selected so the required volume is known, these tank options can be reviewed to determine the cheapest way to provide the needed storage volume.

\section{Tank Solids}

Two types of solids exist in the tanks: suspended solids and heel (settled) solids. Suspended solids will be transferred to the treatment facility along with the liquid waste. The calciner and vitrification alternatives can treat these solids along with the liquid waste. The other treatment processes cannot tolerate solids and they will contain solids separation devices. In these cases, the separated solids will be returned to the Tank Farm to be treated with the heel solids. A definitive disposition plan for heel solids has not yet been developed. An opportunity exists to process the heel solids using the calciner or vitrification alternatives, if the solids are found to be waste incidental to reprocessing and the delivery interface is defined clearly and created by the appropriate project. However, if the solids are classified as High Level Waste (HLW), then this option is not available and the heel solids must be processed as HLW, possibly along with the HLW calcine.

\section{Waste Incidental to Reprocessing}

DOE Order 435.1 requires that HLW be disposed at a national geologic repository (NGR). However, in accordance with this order, waste streams that are determined to be waste incidental to reprocessing (WIR) do not require disposal at the proposed NGR, but may be treated and disposed of as either transuranic waste or low level waste. To satisfy these requirements, WIR determinations must be completed for SBW (including suspended solids) and the heel solids remaining in the waste tanks. Development of the SBW WIR Determination Report is currently in progress. This study will define the cost and schedule for these WIR determinations.

\section{Solids/Liquid Characterization}

The suspended solids and SBW have been characterized sufficiently for the purposes of the calcination alternatives due to the many years of calciner experience. However, the other alternatives have different operating characteristics/chemistries that require specific information that was not of importance for calcination. For example, the Calciner can successfully process waste containing as much as 100 grams/liter undissolved solids, but CsIX and the extraction alternatives are very sensitive to undissolved solids and a solids removal device must be installed ahead of the other process steps. To properly design and test the solids removal device, detailed solids characteristics must be known. The non-calcination alternatives have sensitivities to some chemicals that did not impact calciner operation. For example, the phosphate content must be controlled to assure a quality glass product is made during vitrification. An issue with any alternative is that the detailed analyses required for RCRA compliance cannot be done 
until the liquid waste is in its final form. Over the next three years, the existing SBW will be mixed and concentrated by the High Level Liquid Waste Evaporator. The qualified RCRA analyses cannot be done until this step is completed. 


\subsection{CONCLUSIONS, RECOMMENDATIONS, AND PATH FORWARD}

The conclusions will be discussed that support the recommendations. The path forward will define the activities that support the conclusions and recommendations.

\subsection{Conclusions}

The following conclusions were reached as a result of the alternatives analysis:

1. Based on the established criteria, Risk-based Calcination, MACT to WIPP Calcination, and Cesium Ion Exchange are clearly the top performers.

2. Risk-Based Calcination is a go/no-go decision based solely on the ability to obtain an operating permit.

3. MACT to WIPP Calcination and Cesium Ion Exchange have key uncertainties which must be resolved before a defensible choice can be made between the two.

4. Although assumptions were made during the analysis of alternatives, the disposition path for the waste streams are not guaranteed. Completion of the Waste Incidental to Reprocessing determinations are required for both liquids and solids that remain in the Tank Farm. Formal agreements for waste disposal are required with the disposal sites.

5. Additional characterization of the feed streams is required to support detailed process design.

6. New tankage, which comes on line in 2010 , is required for all alternatives.

7. A plan for tank heel solids management is required so the SBW treatment system can be designed to accommodate them if required.

\subsection{Recommendations}

1. Decide whether to pursue the Risk-Based Calcination option based on the probability of obtaining the permit.

2. If the Risk-Based Calcination option is not pursued:

$>$ Go down dual path (MACT-WIPP \& CsIX) until key uncertainties are resolved

$>$ Focus technology development immediately on key uncertainties

$>$ Initiate Conceptual Design for selected alternatives as soon as required information is available. Conceptual Design must begin no later than July 2000 for MACT-WIPP and April 2001 for CsIX, if the 2012 deadline for treating the SBW is to be met.

$>$ Initiate acceptance of our material into final disposition locations (WIPP \& Hanford)

$>$ Make the final selection when key uncertainties are resolved or validated.

3. Initiate discussions with the State of Idaho regarding SBW classification and disposition.

4. Increase focus on liquid waste feed characterization (and entrained solids characterization if CsIX is pursued).

5. Continue the planning required to support an FY2004 line item project for new liquid waste storage tanks.

6. Develop a tank heel solids management plan so requirements (if any) for these solids can be included in the design of the SBW processing facility.

\subsection{Path Forward}

Until a final selection, BBWI should recommend to DOE-ID that a dual pathway in both technology development and conceptual design be initiated for both MACT to WIPP and CsIX alternatives. The dual path will require BBWI to initiate both conceptual designs in July to give BBWI the ability to meet 2012 and manage the risks remaining with each alternative. Either path requires surge capacity, thus, preconceptual design studies need to continue to be prepared for on time tank delivery. 
Technology road mapping will initially focus on the technology selection and will include development needed to collect the data that will define the effect of the key uncertainties on the technology performance. The initial effort will be followed by the overall technology roadmap, which is to be completed by July 15, 2000, and will identify those activities that need immediate attention to support the final alternative selection.

Programmatically, BBWI needs to initiate acceptance discussions for these specific waste streams with WIPP and Hanford as identified on the alternative flowsheets. Areas of concern dealing with the ability to dispose these wastes could offer discrimination among the two alternatives depending on the success of the discussions and agreements.

Additionally, BBWI, the State of Idaho, and DOE-ID need to discuss the SBW classification and ultimate disposition to avoid contradictory statements that disable INEEL's waste from going to WIPP or Hanford.

Independent of the alternative selected, the lack of characterization data of the entrained solids and concentrated liquid SBW is causing concern with technology performance validation and the required engineering of the implementing facility. Additional BBWI focus on obtaining these needed characterization data is crucial to the success of the SBW project.

New liquid waste storage tanks need to continue to be planned as a FY2004 line item project.

The current effort with Duke Engineering to perform the waste incidental to reprocessing (WIR) determination is essential to the potential off-site disposal in the near term and should be aggressively pursued.

The process and methods used in this analysis will be available in case a promising alternative requires evaluation. These "what-if" type alternative analyses will be coordinated and approved through the HLW Program Office.

Finally, optimization opportunities were identified for some of the alternatives. For instance, the CsIX alternative has a reasonable potential cost savings if the ORNL CsIX facility's design is found to be applicable to the INEEL SBW treatment. Interim storage designs used by Savannah River Site could also be useful in our interim storage concepts that could help the two off-site disposal finalists. Additionally, remote TRU treatment, packaging, and loading for transport must be performed for three different waste stream groups across the INEEL. Appendix M contains the results of site visits to ORNL and West Valley Demonstration Project.

\subsection{Analysis of DOE-ID Management Response}

Upon review of the analysis and results of this effort, management from DOE-ID inputted their insights and understanding relative to the SBW issue. Primarily, it was concluded that, in light of recent, negative response to thermal treatment systems (e.g. Advanced Mixed Waste Treatment Project), that indeed the criterion of Type of Processing should be weighted much more heavily than the other criteria. In fact, additional sensitivity analyses show that upon responding the DOE-ID request of weighting Type of Processing five to ten times higher than the other criteria that the calciner options drop below the options that call for solvent extraction, namely CsIX/TRUEX, TRUEX, and UNEX. Figure 5 shows that it is upon weighting this criterion seven times heavier than the other that this transition occurs. 
Figure 5. Sensitivity Analysis on the "Type of Processing" Criteria

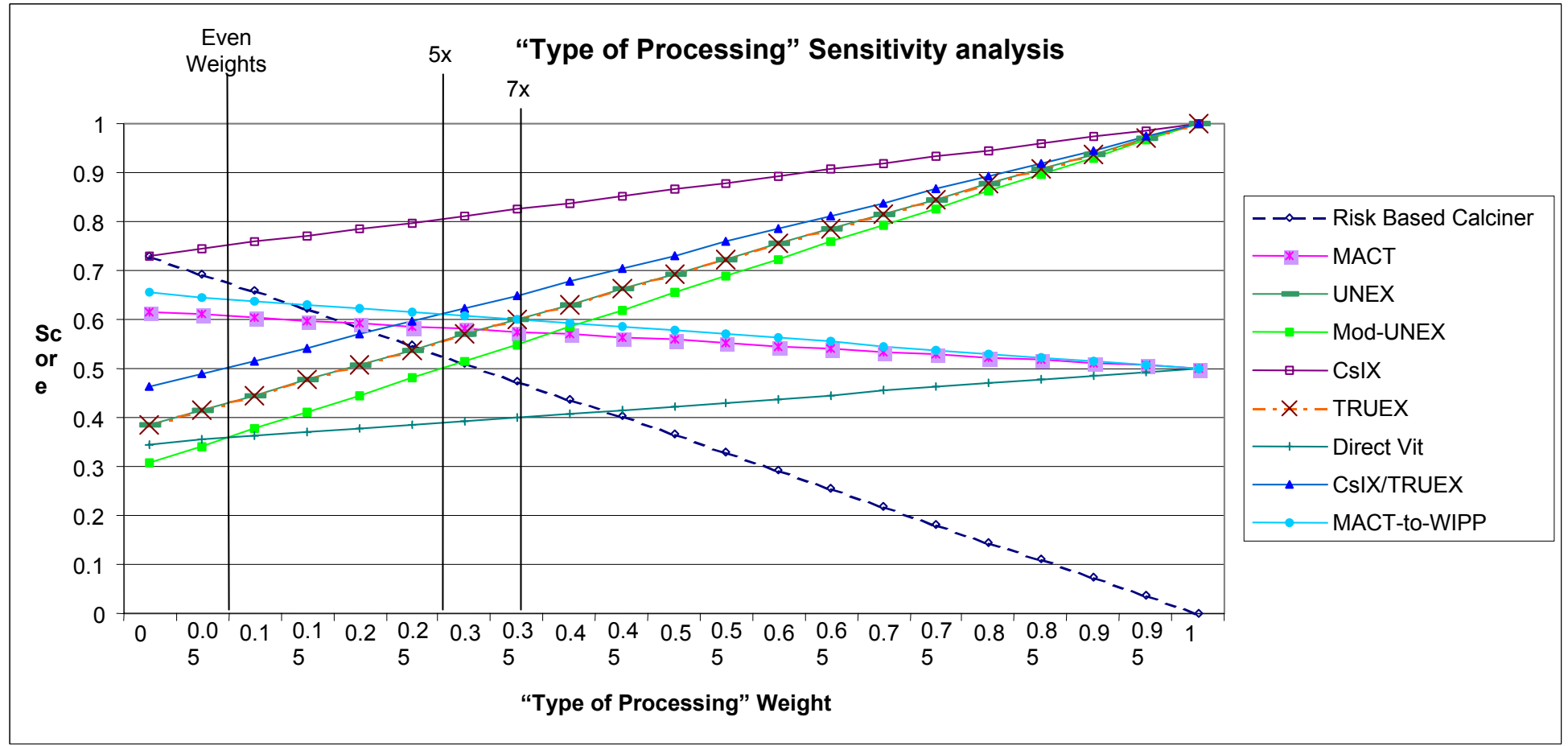

To explain the graph, note that at the vertical line demarcating where all criteria are equal (with the $1 \mathrm{x}$ at the top), then the data stand in the places as indicated in the original sensitivity analysis, with CsIX in first place, Risk-based calciner in second place, and so on. Now, moving to the vertical line where Type of Processing is $5 \mathrm{x}$ as great as the other criteria, note that CsIX/TRUEX is transitioning into second place, with MACT to WIPP and MACT holding third and fourth respectively, but on their way to lower places. Finally, the 7x line shows the final placing of the alternatives, with CsIX in first, CsIX/TRUEX in second, and TRUEX and UNEX in a tie for third place.

The information in this graph leads to a slightly different and yet very tenable conclusion. CsIX is far and away the best alternative for the criteria and weighting considered and should be pursued as the primary alternative. CsIX/TRUEX is a beneficial backup only in a programmatic risk sense, since it does dispose of very little waste at WIPP, and that may be beneficial. However, from the perspective of a parallel path alternative, CsIX/TRUEX would be hampered by any problems that CsIX encounters. Instead, TRUEX and UNEX are independent of the CsIX process, and yet they are clearly too close to call from a quantitative perspective at the time in the analysis. The solvent extraction process must be tested for use of both solvents with a down-select point later. The next section explains in more detail the path forward for the SBW based on this new information. 